\title{
Commercialization of Intellectual Property as Strategical Route for Russian Knowledge-Based Economy Efficiency Improvement
}

\author{
Galina M. GOLOBOKOVA \\ Ph.D. (Technical Sciences), D. Sc. (Economics), Professor \\ Head of Scientific Research Department of Audit, Valuation, Expertise and \\ Standardization of Intellectual Property \\ Republican Scientific Research Institute of Intellectual Property \\ bld. 1, 4, Obrucheva str., Moscow, 119421, Russia \\ E-mail: golobokovagm@inbox.ru
}

\begin{abstract}
Present study aims to search such conditions at which commercialization of intellectual property would be activated in order to improve the efficiency of enterprise activity in various branches of Russian economy. To achieve the goal of the study, an analysis is made of the status of the mechanisms and tools development to increase the effectiveness of innovative activities based on the commercialization of intellectual property. Solution of the tasks set in the work was carried out using theoretical and empirical methods of scientific knowledge: historical, logical, statistical, comparative analysis, abstraction and aggregation. The following results were obtained: the main ways of commercializing of intellectual property were established; features of the use of intellectual property in resource and high-tech sectors of the Russian economy identified; the causes of failures in the innovative development of the studied industries determined; proposals were developed to improve mechanisms to accelerate the commercialization of intellectual property.
\end{abstract}

Keywords: intellectual property; commercialization of intellectual property; capitalization of intellectual property; licensing of intellectual property, intellectual property based lending.

\section{Introduction}

Relevance of the work is determined by the fact that success of the strategic objectives of the innovative economy depends on the effectiveness of promoting the results of intellectual activity, which were created by scientific organizations and for which exclusive rights (intellectual property) are obtained, to producers of innovative products and obtaining economic benefits (commercialization of intellectual property). Today, numerous forums, seminars and conferences are devoted to the protection, management and security of intellectual property. This is due to the fact that innovation is one of the priority areas of public policy. The process of forming a national strategy for the introduction of high technology and the development of high-tech industries is ongoing.

It is well known that intellectual property (IP) is the most important asset of a company that determines its competitiveness in the market. Increase in the value of intellectual property can significantly improve capitalization and credit rating, provide access to new sources of financing, create conditions for alternative areas of cooperation between the private and public sectors of economy in the field of innovation and import substitution (Nikitenko, 2016).

The most important point in an innovative economy is that IP, created on the basis of innovative technologies, implements functions of added value formation, capitalization and investment 
resource; therefore, IP legal protection is a key condition for innovative activity, as it enables companies and, in general, regions to make profit from innovations.

In economically developed countries, governments encourage and support high-tech enterprise ventures through grants, guarantees, subsidies, and / or concessional loans from various financial funds and banks that directly or indirectly recognize the importance of intellectual assets. In many cases, intellectual property is a promising area of investment. A typical example is investment in media assets of corporations such as General Electric and Sony, as well as in patent assets of pharmaceutical companies (Pavlov, 2016). In the countries with the most mature economies, the share of investments in intellectual assets is more than $15 \%$ of gross domestic product (GDP) and more than half of all investments in fixed assets.

In the World Trade Organization (WTO), world trade rules are established both in relation to goods, services, and in relation to intellectual property. According to the WTO, in 2017 the share of payments for the use of intellectual property amounted to $10 \%$ of world exports (World Trade Organisation, 2018). The intellectual property market is undergoing significant structural changes. Today, the share of patent-free licensed sales is close to $80 \%$, which, in turn, was typical for patent sales, but 20 years ago. Thus, we can safely say that the role and importance of intellectual property in all world trade is changing and that intellectual property is the key to the development of hightech industries. For the period from 2012 to 2016, according to the report of the World Intellectual Property Organization (WIPO), industries with the largest number of applications for the registration of results of intellectual activity are: computer technologies (670), telecommunications (308), digital technologies (248), electric machines, medical technologies and pharmaceuticals (slightly less than 200) (World Intellectual Property Organisation, 2018).

So, while in the beginning of the 80 s of the XX century intangible assets accounted for no more than $40 \%$ in the structure of the value of American companies, at the beginning of the XXI century their share exceeded $70 \%$. At the same time, 30-40\% of intangible property was not identified and reflected in the balance sheets of corporations. This suggests that the real share of intangible assets may be even higher. A similar picture is typical for Western European corporations. According to Interbrand consulting company, tangible and intangible assets of well-known companies in the world are correlated as follows: BritishPetroleum - 30:70, IBM -17: 83, Coca-Cola - 4:96. For comparison, in Russia the volume of investments in intellectual property still does not exceed $1 \%$ (Interbrand, 2016). And lending secured by intellectual property rights is generally a new economic mechanism for the commercialization of IP, which only recently began to be actively discussed in literature references (Golobokova, 2019; Marshall, 2014; Golobokova, 2019; Tosunyan, 2017; Belozorova, 2016; Pavlov, 2016) and developed over the past five years for the expanded reproduction of intellectual assets. In general, enough attention has been paid to the issues of IP commercialization in references (WTO, 2018; WIPO, 2018; Interbrand, 2016; Golobokova, 2019; Marshall, 2014; Golobokova, 2019; Tosunyan, 2017; Belozorova, 2016) however, the search for mechanisms and tools that increase the activity and efficiency of commercialization processes has not been adequately covered in literature.

In connection with the growing interest in this subject, the goal of this scientific research was to seek for conditions for intensifying the processes of IP commercialization in companies in various sectors of the Russian economy to increase the efficiency of knowledge-based activities.

To achieve this goal, it was necessary to solve the problems of analyzing the current state of innovation in various sectors of the Russian economy (resource and high-tech) and finding mechanisms to ensure the economic benefits of using the results of intellectual activity in the economic turnover, as well as developing tools to increase the efficiency of IP commercialization. To conduct research on the commercialization of IP selection was made in resource sector, namely, oil production, where there is a sharp increase in competition between manufacturers in its most 
diverse forms: price competition; struggle to seize markets; competition for the right of access to oil and gas resources, and in among high-tech industries chosen was shipbuilding where there is a marked high level of losses from ineffective management of rights to the results of scientific and technical activities created at the expense of the federal budget.

\section{Methods}

The methodological basis of the work is composed of analytical, synthetic and systemic approaches to understanding of the object of study. As theoretical basis of the study were delected the investigations of national scientists Aganbegyan (2009), Glazyev (2017), Davydova (2017), Wachter (2017), in social and economic development and business strategy; Davydova (2019), Korodyuk (2016), Golobokova (2019) in development of the resource and oil and gas complex; Lopatina (2017), Golobokova (2019), Pavlov (2016), Kolmakov (2015), MingYang (2019), Marshall (2014) in the innovative development and formation of the intellectual property market. The subject of lending secured by intellectual property rights is widely discussed in the scientific world and in the business community. In Russia, these processes have attracted attention of many researchers. They find their reflection in works of Lopatin (2014, 2017), Tosunyan (2017), Belozorova (2016), Golobokova (2019), Pavlov (2016), O.F. Maslenkova (2019). The information background of the study was the official data provided by Federal State Statistics Service, Ministry of Economic Development of the Russian Federation, Ministry of Energy, Rospatent reports, materials of the annual International Forum "Innovative Development through the Intellectual Property Market", held at Plekhanov Russian University of Economics (REU), Moscow Institute of Radio Electronics and Automatics (MIREiA) and Moscow State Institute of International Relations (MGIMO) at Ministry of Foreign Affairs of Russia. The research was carried out jointly with scientists from the Baikal State University (BSU), Irkutsk (for oil production matters) and the Republican Scientific Research Institute of Intellectual Property (RSRIIP), Moscow (for shipbuilding aspects) as part of the implementation of scientific research and development work (R\&D) "Elaboration of recommendations on the transfer of rights to the results of intellectual activity belonging to the Russian Federation in the form of a property contribution to the authorized capital of a business company (taking into account specifics of the shipbuilding industry)" and "Establishment of proposals for improving mechanisms to accelerate the implementation of intellectual property results created at the expense of federal budget funds in the shipbuilding industry".

\section{Results}

In course of a scientific study to analyze current status of IP commercialization, as well as to identify problems and opportunities to activate this process in various sectors of the economy (resource and high-tech), it was found out that the main ways of commercializing intellectual property can be the following:

- the use of intellectual property for own production needs with added value;

- capitalization of the organization's assets through intangible assets (intangible assets);

- formation of the authorized capital of the company and its subsidiaries using intellectual property;

- granting the right to use IP under license agreements;

- attracting investments secured by intellectual property (loans, lendings and independent guarantees; source of safeguarding for securities).

At the same time, for the selected industries, along with general problems, significant differences in the use of IP were determined due to the specifics of the innovative development of these industries.

Thus, an analysis of the factors that hinder innovation in Russian companies showed a common 
problem for all industries, namely, among the economic factors the heads of the surveyed organizations name first of all, lack of their own funds (35\% of organizations), which impedes innovation technological nature, adversely affects the quality of implemented innovations and does not allow enterprises to carry out knowledge-based activities on an ongoing basis.

An analysis of the oil industry over the past 30 years (1990-2018) revealed the following main causes of technological backwardness and low levels of economic growth:

1. Transformation of the economic system of the country, consisting in the rejection of the command system, transition to a market management system and intertwined with the processes of globalization, greening, a scientific and technological explosion. If at first the point of view prevailed that this transition would take only years, now it becomes clear that it can stretch for several decades (as practice indicates) (Glazyev, 2017);

2. High level of monopolization of the oil industry led to the fact that monopolistic companies do not consider "breakthrough" innovations as a priority investment target. More than $80 \%$ of industrial enterprises do not associate their strategy with innovation at all;

3. Economic anti-Russian sanctions, especially those related to the oil and gas complex, which hinder development of the industry and hamper transition to introduction of innovative solutions.

At the same time, it was established that the target function of managing intellectual property rights at the regional level is not being implemented, which consists in maximizing the gross value added accrued as a result of commercialization and return on costs incurred for research and development (R\&D) and growth in number of patent applications filed (Kolmakov, 2015).

In terms of investment in R\&D, Russian oil companies lag behind world leaders, with the exception of some companies, such as PJSC TATNEFT and PJSC NK Rosneft. Although Rosneft, in recent years, has significantly increased its R\&D expenditures, catching up with world leaders, the effect of the increase in these expenditures on the number of patents received is not yet visible. On the other hand, in TATNEFT PJSC, R\&D expenses bring a rather large number of intellectual property objects, in particular patents. However, quality of these patents, measured in number of references to them by foreign patents for all Russian companies is extremely low and our patents are almost not in demand during further development and are not commercialized in Russia and abroad, unlike patents of foreign companies (Table 1) (Golobokova, 2019).

Table 1. R\&D costs and quality of unclaimed patents (number of tags by 1 patent)

\begin{tabular}{|c|c|c|c|c|c|c|}
\hline Index & Rosneft & Tatneft & GazpromNeft & Lukoil & Shell & ExxonMobil \\
\hline R\&D costs in revenue $\%$ & 0,7 & 0,3 & 0,2 & 0,0 & 0,4 & 0,4 \\
\hline Number of tags by 1 patent & 0,001 & 0,01 & 0,05 & 0,0 & 0,89 & 0,75 \\
\hline
\end{tabular}

The data in Table 1 evidences a formal approach to $R \& D$ in domestic companies, aimed at reporting on the implementation of innovative development programs (R\&D) and tax benefits. In fact, the result is fundamentally irrelevant or outdated technologies. There are examples when knowledge-based technical solutions appear, but IP is not issued on them and the implementation of such solutions does not lead to commercialization.

Analysis showed that often the reason for failures in innovative development is the incompatibility of the standards of Russian with foreign developments, which complicates the process of their commercialization. According to Rospatent, the number of orders registered in 2014-2018 by the 
exclusive right to inventions, utility models, industrial designs in oil and gas industry is much lower than, for example, in chemical and petrochemical industries (Table 2). At the same time, in giantlike companies such as Shell and ExxonMobil, number of protected solutions is gradually approaching the 20 thousandth mark.

Table 2. Number of orders registered in 2014-2018 by the exclusive right to inventions, utility models, and industrial designs

\begin{tabular}{lccccc}
\hline Sector & 2014 & 2015 & 2016 & 2017 & 2018 \\
& & & & & \\
\hline Oil and gas industry & 135 & 142 & 166 & 146 & 134 \\
Chemical and petrochemical industry & 407 & 406 & 406 & 475 & 510 \\
\hline
\end{tabular}

In the shipbuilding industry, in the face of increasing competition, companies are forced to independently take active steps to solve the strategic and operational tasks of achieving the goals of sustainable economic and social development.

The prospects for the development of national shipbuilding in modern conditions are determined to a large extent by the possibility of creating a Russian innovation system, and this is closely related to the solution of issues of introducing IP into the economic turnover and commercialization. Achieving this goal is impossible without the use of modern market mechanisms for creating and protecting exclusive rights to intellectual property products. Today, problems arise due to the need to commercialize a huge number of scientific and technical results created by companies in the shipbuilding industry, and to organize the protection of intellectual property during export operations with military and technical products and services.

In the framework of the scientific study "Elaboration of recommendations for transferring rights to the results of intellectual activity belonging to the Russian Federation in the form of a property contribution to the authorized capital of a business company (taking into account the specifics of the shipbuilding industry)", an analysis was made of the state of innovative development of the industry and recommendations were developed for transferring rights the results of intellectual activity belonging to the Russian Federation in the form of a property contribution to the authorized capital of a business company (taking into account the specifics of the shipbuilding industry). The work defines a matrix of basic legal relations applicable to the actions of three main categories of entities (the Russian Federation as the copyright holder in the person of the state customer - state corporation - business company) and in 4 cases of making intellectual property in the form of a property contribution to the authorized capital of the business company (taking into account the specifics of shipbuilding industries): when establishing (incorporation) a company; upon recapitalization of company assets; when buying and selling shares in the authorized capital of a company with the replacement of a property contribution; when reorganizing the company.

Another part of the work for the shipbuilding industry in the framework of the research project "Elaboration of proposals for improving the mechanisms for accelerating the implementation of the results of intellectual activity created at the expense of the federal budget in the shipbuilding industry" was the development of proposals for improving the mechanisms for accelerating the implementation of the results of intellectual activity created at the expense of the federal budget. In the analysis of the annual reports of the shipbuilding industry, it was found that in 2017 alone, the industry received 254 patents, 24 know-how, 38 trademarks, 169 computer programs, 53 database certificates, 16 trademark certificates, 248 objects copyright law. However, only $35.1 \%$ of IP objects were implemented. The low activity of implementation, in our opinion, is also explained, as in the oil industry, by an insufficient level of financing and the lack of motivational mechanisms for 
the commercialization of IP. The real market value of the created intellectual property is reflected on the balance sheets of only some enterprises. So, for example, according to the annual reports of the joint shipbuilding company "OSK" JSC, the annual R\&D expenses from 2015 to 2018 amounted to 23474 thousand rubles. The cost of registered intangible assets, according to the balance sheet of "OSK" OJSC as of December 31, was 4631 thousand rubles in 2011, 901 thousand rubles in 2012, and 6175 thousand rubles in 2013. , in 2014 - 6084 thousand rubles, in 2015 - 9599 thousand rubles, in 2016 - 18964 thousand rubles, in 2017 - 30037 thousand rubles, in 2018 125756 thousand rubles. Despite the positive dynamics of growth in the value of registered intangible assets, the effectiveness of the implementation and commercialization of IP of enterprises in the shipbuilding industry is still not up to par.

As a result of the analysis of annual reports and financial statements of a number of enterprises in the shipbuilding industry, the following indicators were calculated for the value of one exclusive right to intellectual property items: 1) for accounting as the value of IP put into record keeping in the form of intangible assets and 2) for costs (the amount of R\&D financing, as a result of which protectable results of intellectual activity (RIA) received). So, for example, in 2014, for the OSK Group of Companies, the average cost of one exclusive right to an intellectual property object (IPO) in accounting, keeping in record the growth in the value of intangible assets due to intellectual activity, referred to the number of exclusive rights to RIA registered for the year, amounted to 99 869 thousand rubles $(2.1 \%$ of non-current assets / the number of exclusive rights to RIA, registered for the year). And the average cost of creating a single exclusive right to intellectual property rights at costs amounted to 60625 thousand rubles. Calculations show that the "average" costs of creating one exclusive right for intellectual property rights, based on R\&D expenses, is significantly lower than the "average" cost of one exclusive right for intellectual property rights put in accounting in the form of intangible assets, which means that the rights were not fully executed and their inventory and registration were not made in the form of intangible assets, or that during the conduct of research, "unregistrable" RIA were obtained. In 2015, for the same company, the cost of one exclusive right to intellectual property item was determined in accounting as the ratio of the increment in the value of intangible assets due to intellectual activity $(2.8 \%$ of non-current assets according to the annual report) to the number of exclusive rights to RIA registered for the year and amounted to 141469 thousand rubles $(2.8 \%)$. The cost of creating one exclusive right to intellectual property item amounted by expenses to 42187 thousand rubles. This suggests that the costs of R\&D were effectively used, while the rights to RIAs were formalized and they were inventoried and registered in the form of intangible assets, either RIAs that brought significant value to the company were obtained. Thus, in the course of research it was found that the high "average" cost of one exclusive right to intellectual property item in accounting indicates a high level of efficiency of ongoing research and development, which ends with obtaining rights to RIA and registration in the form of intangible assets. The medium "average" cost of one exclusive right to intellectual property item in accounting points to the average level of effectiveness of ongoing research and development, which does not always end with obtaining rights to RIA and registration in the form of intangible assets. The low "average" cost of one exclusive right to intellectual property item in accounting speaks for a low level of IP capitalization created on the basis of R\&D, which ends with obtaining rights and registering a large number of RIAs in the form of intangible assets.

The level of IP capitalization could be increased by introducing exclusive rights to the developed RIA in the authorized capital of companies, selling licenses to use IP by other domestic and foreign companies, and using IP as a collateral for loans.

Lending on the security of intellectual property objects, as the newest and most effective way of commercializing IP, will allow the enterprise - holder of intellectual property rights (mortgagor) to improve the conditions for obtaining business financing from investors / creditors (mortgagees), including securing loan obligations, as well as increase efficiency management of its non-current 
capital in terms of intellectual property. A loan secured by rights to intellectual property will be useful to copyright holders to ensure that the full amount of financing costs for design and experimental development, and bringing inventions and other industrial property to the implementation stage. As a compensation, the mortgagor may offer the mortgagee access to the proceeds of the license, or agree to pay them directly to the mortgagee or by providing the mortgage holder with the income stream itself (Marshall, 2014).

Situation with the pledge of exclusive rights to intellectual property objects for 2014-2018 in Russia as a whole and in the banking system in particular, is characterized as stable, while the number of transactions of pledge of exclusive rights to a trademark has steadily increased (Maslenkova, 2019).

To assess the possibility of implementing collateral operations in credit organizations, when the collateral is intellectual property, based on the annual report of Rospatentaz for 2018, we analyzed the dynamics of registration of the pledge of exclusive rights to trademarks from 2014 to 2018, which, however, showed insufficiently high activity in this area (Table 3).

Table 3. Dynamics of registration of a pledge of the exclusive right to a trademark in 2014 2018

\begin{tabular}{lccccc}
\hline Index & 2014 & 2015 & 2016 & 2017 & 2018 \\
\hline Number of registered trademarks & 258 & 362 & 689 & 750 & 829 \\
& 40 & 58 & 72 & 98 & 137 \\
$\begin{array}{l}\text { Volume of pledge of exclusive rights to trademarks } \\
\begin{array}{l}\text { Ratio of pledged trademarks to the number of registered ones, } \\
\%\end{array}\end{array}$ & 15,5 & 16,0 & 10,4 & 13,1 & 16,5 \\
\hline
\end{tabular}

These tables indicate a low level of commercialization of such a common intellectual property object as a trademark, although this method of commercialization would be very useful for companies that do not always have other collateral for obtaining a loan, especially for small businesses.

But to activate lending processes secured by intellectual property, work should be done to inform, formalize and unify the procedures of this method of commercialization. For this purpose, on the basis of the analysis, a standard was developed for management of intellectual property in a credit institution, where the basic procedures and rules for the interaction of market participants were formulated, both when using intellectual property as collateral for lending and when managing your own IP credit organizations, including in the framework of interbank cooperation (Golobokova, 2019).

\section{Discussion}

It will be wise to agree with academician Glazyev (2017) on the need to modernize monetary policy in the country, because there is practically no lending to investments in the development of production. Economic development requires investment, their growth is provided by bank credit. In successfully developing countries, an increase in production is accompanied by an outstripping increase in investments, which are financed by a corresponding increase in bank credit. Thus, a 10fold increase in gross domestic product in China from 1993 to 2016 was accompanied by an increase in investment by 28 times. This illustrates the effect of the growth mechanism of the Chinese economy: an increase in economic activity, as measured by gross domestic product, is ensured by outstripping investment growth, most of which is financed by loans from the state banking system. According to Korodyuk (2016), Russian economy, and, accordingly, the oil 
industry, cannot enter the expanded reproduction mode, they are technologically degraded, and become vulnerable to sanctions. Consequently, the level of innovative development of the industry is one of the main factors of its economic growth, but without intensified government intervention (monetary policy) it is difficult to expect positive results. Unfortunately, in Russia in the information age, an intellectual product is worth little or not in demand. To produce an exclusive, high-quality, not expensive product is by definition unprofitable. It's easier to buy or "copy" it. The new product should become the most expensive one in our country, where the intellectual potential is still quite high. And in the oil industry, where the level of competition is low, monopolistic companies do not consider "breakthrough innovations" as the primary investment target. This is due to the fact that in Russia the system of those few innovative products that the country is considering has not yet been built. It should be worked out how to bring domestic intellectual property products to the world market so that they are quoted on it. According to Tosunyan (2017), a loan in Russia performs extremely poorly its function as a source of economic growth due to high interest rates, and by the end of 2015, only $6.4 \%$ of investments were financed from loans from Russian banks. However, Belozorova (2016) believes that intellectual property can act as additional collateral that reduces the risk of lending to an innovative project or increases the amount and provides preferential terms. It is also necessary to agree with the opinion of scientists that under the new conditions, receipt and implementation of exclusive patent law will be complicated (Wachter, 2017). As a result, more significant attention will be paid to patent strategy issues, as intellectual property management now depends not only on the analysis of patent information. It requires the study of economic, trade, technical, legal, consumer and business information, which big data will integrate into an organic system (Yang, 2019).

\section{Conclusion}

Thus, as a result of the study, it was concluded that one of the most important aspects of technological development is the ability to identify and effectively protect existing unique technological competencies. To solve this problem, Russian companies should establish programs for the development of an IP management system (in terms of inventions, utility models and R\&D results). As a result of the implementation of these programs, companies will introduce a systematic approach to the creation and legal protection of the results of intellectual activity.

To increase the activity and effectiveness of commercialization of IP, as shown by the results of the study, it is necessary to ensure the following:

1. compulsory registration of rights to RIA created during R\&D;

2. registration in the form of intangible assets of all acquired rights to RIA, increasing their value;

3. reduction of "average" costs for the creation of one exclusive right to intellectual property rights, based on the costs of research and development;

4. implementation, to the extent permitted by law, of other types of commercialization of IP (licensing, inclusion in the authorized capital, credit secured by IP);

5. increase in the patent efficiency coefficient "The ratio of the number of intellectual property items introduced into production to the total number of intellectual property items created over the past three years (\%)", while taking into account only inventions and "registrable" knowhow.

Before launching technological projects, it is necessary to assess the potential of creating registrable RIAs and select the optimal form of their legal protection. Only part of the RIA can be protected by patents, and for the most promising scientific elaborations critical for business development, creation of a know-how regime is more appropriate for protection. The main advantage of this approach is that significant information will not "leak" to competitors through publication, as is the case with a patent.

The next conclusion of the conducted scientific research is that process of IP management should 
become an integral part of the technological development of companies, ensuring the use of effective methods of IP commercialization. It is necessary to implement developed IP standards to provide economic and technological literacy regarding the commercialization of exclusive (property) rights to RIA. To increase the mass and efficiency of lending processes on the security of IP, it is necessary to build competencies in credit organizations on the use of IP, which should be based on the study of foreign and domestic experience in using this tool for financing the enterprises that produce innovative products.

To activate the processes of IP commercialization, it is necessary to create and use training and motivation systems as effective tools for the development of an innovative culture. Comprehensive protection of technological developments (patents, works, databases, software, know-how) by companies should minimize the risk of claims by external organizations, and at the same time, companies should receive additional income by reducing the tax base and commercialization of developments.

Thus, results of the study can become a methodological basis for informational, analytical and organizational support of the work on managing the rights on intellectual activity results obtained as part of taking measures of innovative development programs of Russian economy.

\section{REFERENCES}

Aganbegyan, A.G. (2009). Prospects for the socio-economic development of Russia in a crisis. Economics and Management, 2-7.

Interbrand. (2016). Anatomy of Growth. Top Growing Brands. Retrieved from: http://interbrand.com/best-brands/best-global-brands/2016/.

Belozorova, E.N. (2016). Problems of intellectual property collateral in innovative projects. Innovative development through the intellectual property market: VIII international forum, 269-272.

Davydova, G.V. (2017). Sources of economic growth. ISTU Izvestia Vuzov. Investments. Building. The property. 7(4), 52-64.

Glazyev, S.Y. (2017). Why Russian economy is not growing. Arguments of the week, (25), 8-9

Golobokova, G.M, Davydova, G.V., Yakovlev, A.N. (2019). Problems of innovative development of the oil industry based on intellectual property. Intellectual Property Law, 4 (58), 30-34.

Golobokova, G.M. (2019). Prerequisites for the transition to an innovative path of development of the oil industry based on intellectual property. Innovative development through the intellectual property market: XI international forum, 353-366.

Kolmakov, V.V. (2015). An analysis of the impact of venture capital investment on economic growth and innovation: evidence from the USA and Russia. Economic Annals, LX(207), 737.

Korodyuk, I.S. (2016). Energy security as a factor of economic stability. Actual issues of social development in the context of a civilizational approach, 9-14.

Lopatin, V.N. (2014). Intellectual property: the lessons of politics, economics and law, or why there is no intellectual property market in Russia. Intellectual Property Law, 2 (34), 8-19.

Lopatin, V.N. (2017). Intellectual Property as a Resource of Russia's Competitiveness in the Digital Economy. Russian Competition Law and Economics, 4 (12), 10-23.

Marshall, J. (2014). Taking security over patents. Retrieved from: 
III International Theoretical and Practical Conference "The Crossroads of the North and the East (Methodologies and Practices of Regional Development)"

https://www.taylorwessing.com/synapse/march14.html.

Maslenkova, O.F. (2019). Crediting on the security of exclusive rights to intellectual property in Russia: dynamics, features and development paths. Intellectual Property Law, 4(58), 35-40.

Nikitenko, S.M. (2016). Perspectives of Comprehensive Mineral Exploitation Based on The Principles of Public-Private Partnership. IOP Conference Series: Earth and Environmental Science. "International Scientific and Research Conference on Knowledge-Based Technologies in Development and Utilization of Mineral Resources", 45, 2001-2008.

Pavlov, B.P. (2016). Commercialization of intellectual property with collateral lending is the most important instrument of competitiveness. Innovative development through the intellectual property market: VIII international forum, 252-255.

Tosunyan, G.A. (2017). The practice of lending under collateral in the form of intellectual property in Russia. Innovative development through the intellectual property market: IX international forum, 161-162.

Wachter, J. (2017). Big Data and IP business strategy. Retrieved from: http://jorendewatcher.com/2013/11/big-data-ip-business-strategy.

World Intellectual Property Organisation. (2018). World Intellectual Property Indicators. Retieved from: www.wipo.int/publications.

World Trade Organisation. (2018). World Trade Statistical Review. Retrieved from: https://wto.hse.ru/doc_09_02_its.

Yang, M. (2019). Research on Intellectual Property Rights of Electronic Commerce from the Perspective of Big Data. Advances in Economics, Business and Management Research. Retrieved from: https://dx.doi.org/10.2991/ssmi-18.2019.73. 